\title{
“Heightened Mindfulness" in Government Decision Makers: Antecedents and Consequents During Crisis Management in the Emerging Interactive Information Environment
}

\section{Sample Exhibits of Grounded Theory Research Operationalisation}

The purpose of this Appendix is to give a glimpse of the research methodology operationalisation followed in the underlying thesis research. Over the period of months, while the researcher went over the news and media reports, voluminous notes and reports gathered from various sources, including, nearly 25 plus books exclusively covering the three crises case studies, besides others covering parts thereof, it required constant going back and forth, over and over again, to gather one's thoughts and scribbled notes into some coherence, so as to finally emerge in the form of open, axial and selective coding results shown in the thesis report.

Illustrative extracts from this process for the Kandahar crisis are presented below, organised as under:

Open Coding

(a) Chronological sequencing of crisis events and associated significant observations arrived at by triangulation method (upto arrival of IC-814 in Kandahar only).

(b) Scheme for coding of level of information exchange between the government decision makers and the public/media.

(c) Coding of level of information exchange between the government decision makers and the public/media through the major crisis stages.

(d) Developing Categories in terms of their properties and dimensions (not shown here, but applied/discussed in the paper and incorporated in the framework) Axial Coding

(e) An example of a Paradigm Model (reflecting important linkages associated with the selected category).

Selective Coding

(f) Integrating situational variations from within and across cases into a Conditional Matrix. 
(g) Integrating "process"-An example of "Deviation Amplifying Mutual Causal Relationships." (see Figure 2 in the paper; also, Figures 1 and 3 in the paper for other examples of this)

\section{Chronological Sequence: IC-814 Kandahar Hijack 1999 Crisis}

(upto arrival in Kandahar)

\begin{tabular}{|c|c|c|}
\hline$\frac{\text { Date \& }}{\text { Time }}$ & Event & $\underline{\text { Remarks }}$ \\
\hline \multicolumn{3}{|l|}{$24 \overline{\mathrm{Dec}}$} \\
\hline 4.05 p.m. & $\begin{array}{l}\text { IC-814 takes off } \\
\text { from Kathmandu }\end{array}$ & \\
\hline 5.10 p.m. & $\begin{array}{l}\text { IC-814 hijacked } \\
\text { over Lucknow }\end{array}$ & $\begin{array}{l}\text { Denied permission to land at Lahore; turns back to Amritsar; } \\
\text { response of the CMG, NSG, Aerodrome Committees, and the } \\
\text { Air Force }\end{array}$ \\
\hline 7.01 p.m. & Lands at Amritsar & Missed "window of opportunity" \\
\hline 7.49 p.m. & $\begin{array}{l}\text { Takes off from } \\
\text { Amritsar }\end{array}$ & $\begin{array}{l}\text { Poor information dissemination to affected public; crisis } \\
\text { management machinery fails to respond at all levels; } \\
\text { responsibility disowned, "passing the buck" }\end{array}$ \\
\hline \multirow[t]{2}{*}{8.07 p.m. } & Lands at Lahore & Diplomatic level contact with Pakistan initiated \\
\hline & $\begin{array}{l}\text { Takes off from } \\
\text { Lahore }\end{array}$ & $\begin{array}{l}\text { Another possible opportunity lost, as dithering continues at } \\
\text { the Government level; role of NSG/anti hijack forces? }\end{array}$ \\
\hline \multicolumn{3}{|r|}{ (2) } \\
\hline 1.30 a.m. & Lands at Dubai & $\begin{array}{l}\text { Diplomacy activated, but forced action options restrained by } \\
\text { local government; some negotiations; } 26 \text { women and children } \\
\text { released; body of Rupin Katyal handed over }\end{array}$ \\
\hline 6.30 a.m. & $\begin{array}{l}\text { Take off from } \\
\text { Dubai }\end{array}$ & $\begin{array}{l}\text { Efficacy issues of international diplomacy; question of } \\
\text { inadequate exercise of right to rescue Indian nationals?; } \\
\text { contingency planning?; intelligence gathering? }\end{array}$ \\
\hline $\begin{array}{l}8.30 \text { a.m.- } \\
9 \text { a.m. }\end{array}$ & Lands at Kandahar & $\begin{array}{l}\text { To negotiate or not to; limited channels of communication; } \\
\text { attitude/approach to hijackers' demands; international } \\
\text { pressure activation; gathering of intelligence; proactive use of } \\
\text { the media vis-à-vis easy awareness to the hijackers (through } \\
\text { the media) of the government's state of affairs/despondency? }\end{array}$ \\
\hline
\end{tabular}

\section{Category: Information Exchange by the Government During the Crisis}

\section{Scheme for Coding:}

Level of information exchange has been coded as shown below:

\begin{tabular}{|l|l|l|}
\hline Code & Type & Definition \\
\hline 0 & Nil & $\begin{array}{l}\text { Absolutely no information exchange with the affected } \\
\text { persons/media }\end{array}$ \\
\hline 1 & Low & $\begin{array}{l}\text { Low, i.e., inadequate information exchange, which is not enough } \\
\text { to satisfy the questions raised by the affected people and the } \\
\text { media; leaves dissatisfaction due to this shortcoming }\end{array}$ \\
\hline
\end{tabular}




\begin{tabular}{|l|l|l|}
\hline 2 & Normal/adequate & $\begin{array}{l}\text { People and the media generally agreed that information exchange } \\
\text { meets their requirement; some questions and doubts may be left } \\
\text { unanswered, but these cause no great dissatisfaction }\end{array}$ \\
\hline 3 & High & $\begin{array}{l}\text { Initiative on the side of the government, which is itself } \\
\text { forthcoming with information; government wooing of the media } \\
\text { and the people for transfer of information }\end{array}$ \\
\hline 4 & Maximum & $\begin{array}{l}\text { Out and out proactive efforts by the government to share } \\
\text { information with the people and the media }\end{array}$ \\
\hline
\end{tabular}

Coding of Information Exchange during the Crisis*

\begin{tabular}{|c|c|c|c|}
\hline Period & $\underline{\text { Description }}$ & $\frac{\frac{\text { Level of }}{\text { Information }}}{\text { Exchange }}$ & Comments \\
\hline $\begin{array}{l}\text { Post-hijack- } \\
24 / 12 \text { (4.39- } \\
7.49 \text { p.m.) }\end{array}$ & $\begin{array}{l}\text { Immediate period } \\
\text { following the crisis }\end{array}$ & 0 & $\begin{array}{l}\text { Rise of rumours, misinformation; } \\
\text { hostages' relatives in anxiety; } \\
\text { media hounding for information }\end{array}$ \\
\hline $\begin{array}{l}\text { 24/12 (8.07p.m.)- } \\
\text { 25/12 (8.30 a.m.) }\end{array}$ & $\begin{array}{l}\text { Events at } \\
\text { Karachi/Dubai, till } \\
\text { arrival at Kandahar }\end{array}$ & 0 & $\begin{array}{l}\text { Victims unable to authenticate } \\
\text { information being beamed over } \\
\text { the various media; uncertainty, } \\
\text { fear increases }\end{array}$ \\
\hline $25 / 12$ to $26 / 12$ & $\begin{array}{l}\text { Period of no } \\
\text { dialogue with } \\
\text { hijackers; indirect } \\
\text { communication only }\end{array}$ & 1 & $\begin{array}{l}\text { Government crisis management } \\
\text { process - invisible; media } \\
\text { barrage and highlighting of } \\
\text { victim's plight }\end{array}$ \\
\hline $\begin{array}{l}27 / 12 \text { to } 28 / 12 \\
\text { (trigger for } \\
\text { forced action by } \\
\text { victims: } 1 \text { p.m. } \\
\text { deadline) }\end{array}$ & $\begin{array}{l}\text { Negotiations with } \\
\text { the hijackers, after } \\
\text { threat to kill hostages }\end{array}$ & 2 & $\begin{array}{l}\text { Gate-crashing tactics by victims } \\
\text { to draw attention; force } \\
\text { government to attend to } \\
\text { concerns; seek promises to } \\
\text { resolve crisis satisfactorily }\end{array}$ \\
\hline $28 / 12$ to $31 / 12$ & $\begin{array}{l}\text { Terms of negotiation } \\
\text { for ending the } \\
\text { crisis-bargaining } \\
\text { phase }\end{array}$ & 1 & $\begin{array}{l}\text { Pressure of public commitment; } \\
\text { government resolve weak; leads } \\
\text { to tame surrender }\end{array}$ \\
\hline
\end{tabular}

* Note: Links to data files/references not shown here, which provided facts and basis for the coding. 


\section{$\underline{\text { An Example of "A Paradigm Model" (also referred to as a Logic Diagram) }}$}

In grounded theory, categories and subcategories are linked together in a "set of relationships denoting causal conditions, phenomenon, context, intervening conditions, action / interactional strategies, and consequences" (Strauss and Corbin, 1990: 99). The simplified model looks something like under:
(A) Causal Conditions
(B) Phenomenon
(C) Context
(D) Intervening Conditions
(E) Action/Interaction Strategies
(F) Consequences.

An example with regard to the category "Information Availability to Stakeholders" is shown below.

\begin{tabular}{|c|c|}
\hline$\underline{\text { Causal conditions }}$ & $\underline{\text { Phenomenon }}$ \\
\hline $\begin{array}{l}\text { State of Secondary Crisis Victims \& Media: } \\
\text { Lack of information of the goings-on } \\
\text { Lack of empathy } \\
\text { Temporal match of level of information } \\
\text { exchange to phenomenon }\end{array}$ & Increased anxiety \& frustration \\
\hline$\underline{\text { Context }}$ & State of agitation $\&$ building up of tension \\
\hline $\begin{array}{l}\text { Ongoing crisis-Uncertainty and anxiety } \\
\text { Lives of primary crisis victims at risk } \\
\text { An unresponsive government, with not-too- } \\
\text { successful track record of dealing with } \\
\text { similar crisis } \\
\text { Situation aggravated by the seemingly } \\
\text { lackadaisical attitude displayed by } \\
\text { government/bureaucracy }\end{array}$ & $\begin{array}{l}\text { Trigger (in form of a serious threatening } \\
\text { likelihood—approaching hijacker's deadline) } \\
\text { Resort to disruptive measures to press for } \\
\text { demands }\end{array}$ \\
\hline
\end{tabular}


$\underline{\text { Intervening Conditions }}$

Structural Factors: Power:- Force projection capability; Special forces' preparedness; Intelligence

Diplomatic Standing:- Bilateral agreements of cooperation; Capability to leverage and apply pressure

\section{$\underline{\text { Action/Interaction Strategies }}$}

Misreading of the developing crisis and stakeholders' feedback and concerns

Lack of empathy towards the crisis victims- deficiency in value terms

Lack of strong assertive leadership: To coordinate responsiveness, signalling effects, initiate 'sensemaking', come to grips with the crisis expeditiously,

Consequences and exert positive control on the evolving situation

Increased criticism in media due to slant of coverage — outcome of emerging technology and societal interface in form of infotainment; societal norms

Wider stakeholder generated pressure on government decision makers

Depiction of the Government as a 'soft state' in international geo-political context, as well as towards internal stakeholders

$\underline{\text { Subsequent developments related to the above category as Government begins to redress any }}$ further deterioration of situation:

Attempts to correct the above deficiency by:

Special 'secondary victims' and media briefings - reaching out

Projection of independent expert / analyst opinion in support of government actions, also incorporating them in advisory capacity

Simultaneous action to generate consensus with other major political parties

Orchestrated show of support to government crisis management by its supporters

\section{Consequences:}

Positive response from the secondary victims and reduction of bias in media coverage

Appreciation of the complexity of the evolving situation in interactions over the emerging ICT environment

Reduced pressure on government decision making

Environmental support to ongoing crisis management efforts 
An Example of Integration of Situational Variations from Within and Across

Cases to Formulate Theory

\begin{tabular}{|l|l|l|l|l|}
\hline & $\begin{array}{l}\text { Government } \\
\text { Response to the } \\
\text { Crisis (in the } \\
\text { immediate context) } \\
\text { Speed and Esteem }\end{array}$ & $\begin{array}{l}\text { Government Response } \\
\text { to the Crisis (in the } \\
\text { subsequent context) } \\
\text { Esteem of Action } \\
\text { Orientation }\end{array}$ & $\begin{array}{l}\text { Responsiveness } \\
\text { and } \\
\text { Transparency }\end{array}$ & $\begin{array}{l}\text { General } \\
\text { Awareness } \\
\text { of Crisis } \\
\text { Context }\end{array}$ \\
\hline Kargil crisis & $\begin{array}{l}\text { Initially - Low } \\
\text { Subsequently - } \\
\text { Correction of error }\end{array}$ & High/Certain & $\begin{array}{l}\text { Initially - } \\
\text { Uncertain } \\
\text { Subsequently - } \\
\text { High/Slightly } \\
\text { ambiguous }\end{array}$ & High \\
\hline $\begin{array}{l}\text { Kandahar } \\
\text { crisis }\end{array}$ & $\begin{array}{l}\text { Initially - Low } \\
\text { Subsequently - } \\
\text { Low/Neutral }\end{array}$ & Low/Confused & $\begin{array}{l}\text { Initially - Low/ } \\
\text { poor } \\
\text { Subsequently - } \\
\text { Forced, slightly } \\
\text { better }\end{array}$ & Low \\
\hline
\end{tabular}

